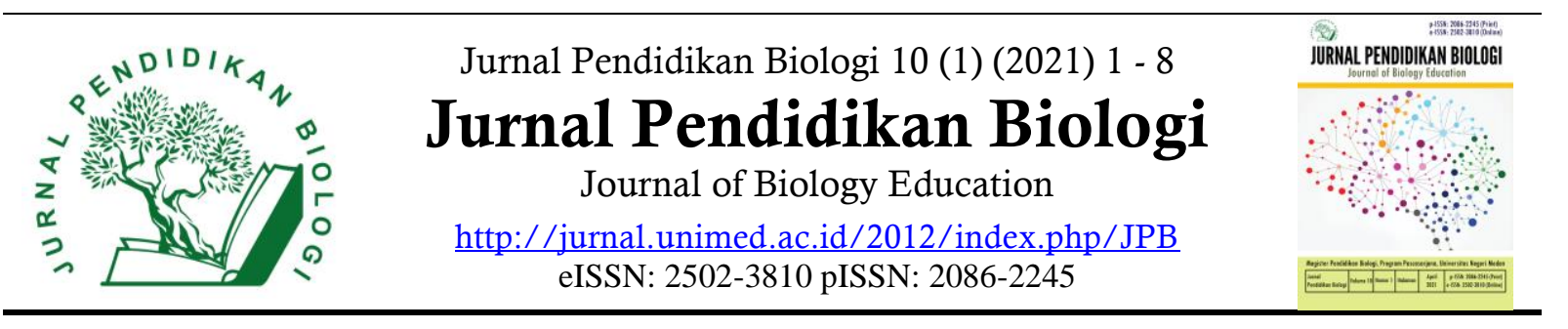

\title{
Guided Discovery in Genetic Learning: Implementation and Impact on Higher-Level Thinking Skills
}

\author{
Fitri Laela Rahmadhani, Fuad Jaya Miharja, Atok Miftachul Hudha \\ Biology Education Study Program, Faculty of Teaching and Education Sciences (FKIP), University of \\ Muhammadiyah Malang Jl. Raya Tlogomas No 246, Malang, 65145, East Java, Indonesia
}

INFO

\section{History}

Received 16 November 2020

Revised 17 February 2021

Accepted 1 March 2021

Published 20 March 2021

\begin{abstract}
The challenges of 21 st century education today require students to have highlevel thinking skills given the many dynamic changes that occur in the field of education. High-level thinking skills are divided into several aspects including critical, creative and collaborative thinking skills. One of the appropriate learning model to improve critical thinking in students is the guided discovery model. The purpose of this study was to determine the implementation of guided discovery. Model in learning genetics to increase higher thinking skills of students of SMAN 1 Lawang which include critical, creative, and collaborative thinking skills. This quasi-experiment was carried out by means of a pre-test and post-test control group design. The sample involved in this study is student of class XII IPA 3 (experiment class and student of class XII IPA 4 obtained by purposive sampling techniqueThe results showed that there are differences in the critical, creative and collaborative thinking skills of students who studied with the guided discovery model with a level of significance $<0.05$. The implementation of the guided discovery model can increase the level of critical, creative and collaborative thinking skills of students of SMAN 1 Lawang. This increase can be seen from the post test results of the experimental class, which are higher than the control class; the ability to analyze the results of the practicum that the experimental class has done; the creativity of students in processing and utilizing laboratory tools and materials; and the collaborative attitude of the students when participating in practicum activities.
\end{abstract}

Copyright (C) 2021 Universitas Negeri Medan. Open Access article under license CC-BY-4.0 (https://creativecommons.org/licenses/by/4.0)

\section{How to Cite}

Rahmadhani, F. L., Miharja, F. J. \& Hudha, A. M. (2021). Guided Discovery in Genetic Learning: Implementation and Impact on Higher-Level Thinking Skills. Jurnal Pendidikan Biologi, 10(1), 1-8.

\section{INTRODUCTION}

This 21 st century education is marked by the integration of science and technology and the development of high-level thinking skills for each individual. A similar opinion was expressed by Widodo \& Wardani (2020), that currently 21 st century education requires every student to have high-level thinking skills considering the dynamics of changes that occur in today's society. According to Anantyarta \& Sari, (2017), high-level thinking skills consist of several aspects, namely critical thinking skills, communication, creativity, and collaboration. Critical thinking is the high-thinking ability needed at this time to make a decision among the large amounts of information which is perceived to be less accurate (Purwanto, 
Nughoro, \& Wiyanarto, 2012). In addition to critical thinking, collaborative attitudes and creativity are aspects that need to be developed in the $21^{\text {st }}$ century learning. One way to develop these two aspects is by assigning a project that involves a group of students, so that they can work together and find creative ideas to complete the project (Sudarisman, 2015). According to Redhana (2019), collaboration is indispensable in creating a superior project or product. One of the learning materials that can be used as a forum to improve these higher thinking skills is genetics learning.

Genetics learning studies the inheritance of traits in an organism. Some of the material studied in genetics itself includes genetic material (genes, DNA, and chromosomes); gene relationship, DNA-RNA-polypeptide and protein synthesis processes; the principle of heredity and the mechanism of inheritance; gender determination; the relationship between mitotic and meiotic division with inheritance; and mutations (Sarhim \& Harahap, 2015). In learning activities, even to this day there are still frequent misconceptions surrounding genetic material. The occurrence of misconceptions in genetic material is due to its abstract and invisible nature, which only allows for reasoning instead (Sarhim \& Harahap, 2015). In addition, the learning model used still tends to be teacher-centered, so that student involvement is still lacking and their learning motivation decreased. Misconceptions regarding genetics occur because students only understand the theory but are not trained in criticizing the real concept of genetics. In addition, by applying the classical method students cannot develop creative ideas nor apply a collaborative attitude in understanding the concept of genetic material. Miharja et al. (2019) argued that the effort that can be made to make genetic material easily understood by students is to improve critical and metacognitive thinking to influence the achievement of cognitive learning outcomes, especially in understanding the concept of genetics.

One model that is often used today in learning genetics is Problem-Based Learning (PBL), a learning model that focuses on students to actively solve a problem related to the material that they are currently learning (Darmawati, Amelia, \& Srifatimini, 2011). According to Wasonowati, Redjeki, \& Ariani (2014), the PBL model has several advantages, including training the ability to think critically, providing satisfaction to students for being able to solve a problem, increasing student activity and the ability to find creative ideas in order to solve a problem during learning process. In addition to PBL, to this day there are a number of teachers who are still applying the conventional learning model by only explaining the material then assigning several students to answer pre-determined questions (Hera, 2017). From the two models, students become trained to have critical thinking skills and creativity only from answering questions given by the teacher, while collaborative attitudes are nurtured in learning activities. Collaborative attitude must to be developed among students, given the challenges of $21 \mathrm{st}$ century education that involve higher level thinking skills, which consist of critical thinking, communication, creativity, and collaborative thinking. To be able to develop these three aspects, it is necessary to apply the guided discovery learning model.

The guided discovery model is one of the learning models which directs students to activities that can develop systematic, logic, and analytic identifying skills, so that they can formulate their own findings (Purwanto et al., 2012). According to Musfiroh, Susantini, \& Kuswanti, (2012), guided discovery can motivate students to learn by being directly involved in the concepts and principles of existing materials, while the teacher is primarily in charge of providing direction and motivating students to gain knowledge as well as experience. Based on the said background, it is necessary to conduct a study on "Guided Discovery in Genetic Learning: Implementation and Impact on Higher Level Thinking Skills "to determine whether the application of guided discovery has an effect on the improvement of critical thinking, creative thinking, and collaborative attitudes of students of SMAN 1 Lawang in learning genetic material. 


\section{MATERIALS AND METHODS}

\section{Procedure}

This study is a quasi-experimental study with a pre-test and post-test control group design. The samples were students in grade 12 MIA 3 (experimental class) and grade 12 IPA 4 (control class) at SMAN 1 Lawang. The designs are presented in Table 1.

Table 1. Research Design

\begin{tabular}{lccc}
\hline Group & $\begin{array}{c}\text { Pre- } \\
\text { test }\end{array}$ & Treatment & $\begin{array}{c}\text { Post- } \\
\text { test }\end{array}$ \\
\hline $\begin{array}{l}\text { Experiment } \\
\text { Group }\end{array}$ & $\mathrm{O}_{1}$ & $\mathrm{X}$ & $\mathrm{O}_{2}$ \\
\hline Control Group & $\mathrm{O}_{3}$ & & $\mathrm{O}_{4}$ \\
\hline
\end{tabular}

\section{Information:}

O1 and O3: The experimental group and the control group were both given a pretest.

$\mathrm{X}$ : Treatment in the form of implementing the guide discovery method in the experimental group.

O2: Posttest in the experimental group after the implementation of the guide discovery method in the experimental group.

O4: Posttest in the experimental group after the implementation of the guide discovery method in the control group

This study used a guided discovery model by measuring the initial ability of students about chromosome cleavage material through giving pretest questions in both classes, followed by experimental class. The treatment given in the experimental class is the application of a guided discovery model in genetic learning. This is done by creating chromosome cleavage preparations using shallots and garlic roots.

During the practicum activity, the process of assessing the creativity and collaborative level of the experimental class students was carried out by examining the students' skills in processing and utilizing chemical tools and materials during practicum and the ability of students to work together in groups. After participating in practicum activities, students are asked to analyze the results of the observations that have been made on the worksheets prepared by the researcher and then present their observations through the google meet platform. The next activity is to reassess the students' level of understanding by giving post-test questions in the experimental class and control class. The results of the assessment of pretest, post-test questions and student activities in following the practicum were then processed using the SPPS software.

\section{Data Analysis}

The data was then analyzed using the ANACOVA test after it was spread normally and homogeneously. Differentiation test was conducted with a confidence level of $95 \%$.

\section{RESULT AND DISCUSSION}

\section{Improvement in Critical Thinking}

Students' critical thinking skills were observed from the pre-test and post-test results. Table 2 shows that the mean post-test scores among students in the experimental class were slightly higher than the control class. However, the ANOVA test results show that there were differences in the students' critical thinking when learning genetics, with a significance of $0.035(<0.05)$.

Table 2. The average posttest score

\begin{tabular}{ccc}
\hline Post-test & Number of Student & Average \\
\hline Experiment Group & 25 & 76.90 \\
Control Group & 36 & 74.22 \\
\hline
\end{tabular}

Based on Table 2, there is no significant difference between the post-test results of the two classes, but the average post-test scores are different. Experimental class students have a higher posttest average than the control class students. This difference is due to the ability to 
analyze and understand the post-test questions. In addition, the students' critical thinking skills in the experimental class were also seen when presenting their observations during practicum through google meet and in the observation sheets that were provided by the researcher. The analytical ability of students who learn with the guided discovery method is better than those who do not learn with guided discovery, because students not only understand the concepts and material about chromosome cleavage from the explanation of the material by the teacher, but also from the practicum activities they participated in. According to Handayani, Sunarto, \& Sumarti (2017), by applying the guided discovery model, students can foster critical and creative thinking to find out more about the material they are learning. A similar opinion was also expressed by Roosyanti, (2017), that one way to train students' critical thinking skills is by applying the guided discovery model, where students are guided to learn like scientists and discover information in their surroundings.

Table 3. ANACOVA test results for critical thinking skills

\begin{tabular}{llcccc}
\hline Source & Type II Sum of Squares & df & Mean Square & F & Significant \\
\hline Corrected Model & $346.755 \mathrm{a}$ & 2 & 173.378 & 3.054 & .055 \\
Intercept & 3998.989 & 1 & 3998.989 & 70.443 & .000 \\
Aspek Penilaian & 266.081 & 1 & 266.081 & 4.687 & .035 \\
Error & 3235.845 & 57 & 56.769 & & \\
Total & 362100.000 & 60 & & & \\
Corrected Total & 3582.600 & 59 & & & \\
\hline
\end{tabular}

The application of this learning model practically makes students investigators, since they are given the opportunity to observe, analyze and draw conclusions from the practicum activities they do (Handayani et al., 2017). According to Noviyanti, Ristanto, \& Rusdi (2019), the application of the guided discovery model can build learning motivation in students, and this learning motivation is one of the internal factors that determine the success of learning and the level of students' critical thinking. Monroe \& Ernst (2014) bargues that critical thinking is a process that aims to encourage students to solve a problem and be able to make a decision from what they investigate themselves in the learning activities that they participate in. Critical thinking skills are the key for someone to have sensible thinking, gather relevant information efficiently and creatively, and be able to sort various accurate information. (Cheong \& Cheung, 2008).

\section{Improvement in Student Creativity}

Based on the ANACOVA test that has been carried out, the significance value of the creativity level assessment data was obtained as shown in Table 4. Table 4 shows that the significance level of student creativity is $<0.05$, so it can be said that there is a difference in the creativity of students who followed the guided discovery learning method. The creativity of the experimental class students can be seen in how they make good use of existing chemicals (Figure 1) and laboratory equipment (Figure 2), especially when making preparations. The existence of these activities will encourage students to experiment to find something new. 
Table 4. ANACOVA test result student creativity

\begin{tabular}{llcccc}
\hline Source & Type II Sum of Squares & df & Mean Square & F & Significant \\
\hline Corrected Model & $704.167 \mathrm{a}$ & 1 & 704.167 & 82.476 & .000 \\
Intercept & 12355.350 & 1 & 12355.350 & 1447.122 & .000 \\
Aspek Penilaian & 704.167 & 1 & 704.167 & 82.476 & .000 \\
Error & 187.833 & 22 & 8.538 & & \\
Total & 186748.000 & 24 & & & \\
Corrected Total & 892.000 & 23 & & & \\
\hline
\end{tabular}

The findings they obtained made the experimental class students better understand the mitotic cleavage material, besides that they were also able to think creatively in presenting their findings in the student observation sheets that had been prepared previously. This guided discovery model, in addition to being able to train students to think critically about their experiment findings, can also train them to be more creative and active in solving a problem because students would be directly involved and guided to understand the concepts that are being studied.

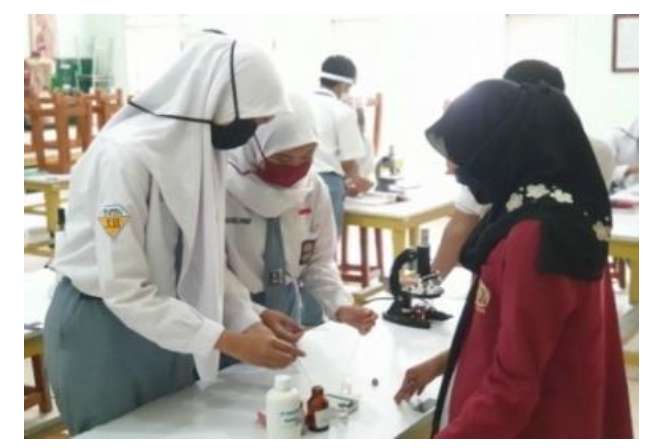

Figure 1. Students' skills in using chemicals

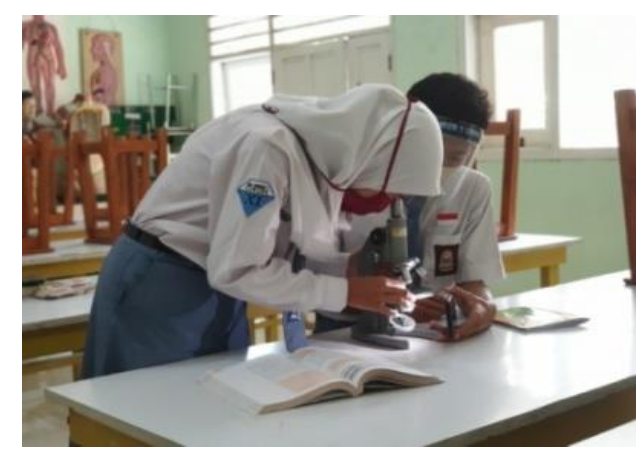

Figure 2. Students observing the preparations using a microscope
According to Handayani et al (2017), the existence of a guided discovery model not only trains students to think critically, but also requires students to be active and creative in learning activities. This is because learning is an active process for students in order to understand the concepts developed through guidance. A similar opinion was expressed by Rochayati, (2016), who argued that students' creativity was not sufficiently honed just by inviting them to understand the material in the worksheets or books, but also by including them in an experiment according to the learning material at hand, so that they could clearly know from whence the concept or material being studied was founded. Human creativity needs to be trained from an early age so that each individual can adapt their existing abilities, which can then be developed for their personal progress, especially in the field of education and profession. Each individual should be able to develop creativity, including generating new ideas for creative problem solving (Collard \& Looney, 2019). Creative thinking skills enable students to generate and expand ideas to suggest hypotheses, apply their imagination, and produce innovations (Craft, 2012). The application of guided disvovery model in learning activities in class trains students to solve a problem by directly engaging in learning activities and generating new ideas to solve it. 


\section{Improvement in Student Collaboration}

Based on the ANACOVA test that has been carried out, the significance value of the creativity level assessment data is shown in Table 5. Table 5 shows that there is an effect of implementing guided discovery on student collaborative improvement (sig <0.05). The results of the assessment of cooperation between group members in the implementation of practicum have an average value of 93.32 from 25 students, who were divided into 12 groups. Practical activities that were followed by 12 IPA 3 students indirectly trained students to cooperate with each other cooperatively with group members (Figure 3).

Table 5. Student collaborative ANACOVA test results

\begin{tabular}{llcccc}
\hline Source & Type II Sum of Squares & df & Mean Square & F & Significant \\
\hline Corrected Model & $873.212 \mathrm{a}$ & 1 & 743.846 & 72.836 & .000 \\
Intercept & 27806.381 & 1 & 167235.780 & 1627.262 & .000 \\
Aspek Penilaian & 637.139 & 1 & 715.185 & 91.362 & .000 \\
Error & 194.665 & 20 & 8.961 & & \\
Total & 178462.020 & 22 & & & \\
Corrected Total & 944.008 & 24 & & & \\
\hline
\end{tabular}

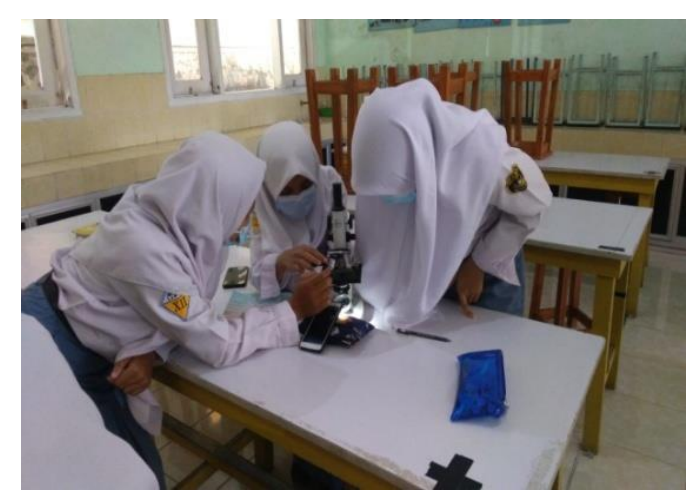

Figure 3. Coordination and discussion conducted by students in groups

In addition to fostering a cooperative attitude, learning with the guided discovery model trains students to communicate and exchange ideas or ideas to solve a problem with their group members. (Anantyarta \& Sari, 2017).

According to (Inganah, Jamil, \& Dintarini, 2018) collaborative learning is where students who display different levels of academic learning are grouped together to achieve specified objectives. Nurkamila, (2017) also argues that collaborative learning is learning in groups, where students learn together, discuss, exchange opinions to achieve learning goals. The conclusions obtained do not represent the group, but rather are the results of students' inferences based on their interactions with their fellow group partners. A similar statement was also submitted by (Utami, 2013), that with collaborative learning, students can be trained to interact with others, exchange ideas and opinions to achieve common goals, taking into account that in the future they can be faced with the needs for collaboration and cooperation with others in the professional world. Collaborative learning can organize student learning activities by inviting small groups of students to participate in goal-directed activities and to practice interacting with others both verbally and socially (Puzio, Colby, \& Colby, 2013).

Laal \& Mohammad (2012) explained some of the benefits of collaborative learning, which include developing a social support system for students, building students' understanding of various differences of opinion between them, and being able to develop a fairly good learning community. Similar 
opinions are also submitted by Dormalewska, (2014) who stated that collaborative learning is a form of social activity between students that involves project-based learning, which also utilizes technology to support the learning process. In addition, this collaborative learning can develop skills and acquire more knowledge while maintaining relationships with their classmates. With this collaborative learning, students are expected to be able to socialize both with friends and with the community around them, especially when they start working in the marketplace(Inganah et al., 2018).

\section{CONCLUSION}

Based on the results of this study, it is therefore concluded that the implementation of guided discovery in learning genetics can improve the critical thinking, creativity, and collaborative thinking skills of students in grade 12 at SMAN 1 Lawang. This can be seen from the post-test results of class 12 MIA 3 (experimental class) which is higher than class 12 MIA 4 (control class), with the ability to analyze the results of practicum which is quite good. In addition, increasing student creativity and collaboration can be seen from the skills of grade 12 MIA 3 (experimental class) in properly processing and utilizing chemical equipment and materials in the laboratory as well as good cooperation between students during practicum activities.

\section{BIBLIOGRAPHY}

Anantyarta, P., \& Sari, R. L. I. (2017). Ketrampilan kolaboratif dan metakognitif melalui multimedia berbasis mean ends analysis. Jurnal Biologi Dan Pembelajaran Biologi, 2(2), 33-43.

Cheong, C. M., \& Cheung, W. S. (2008). Online discussion and critical thinking skills: a case study in a Singapore secondary school. Australasian Journal of Educational Technology,
24(5), 556-573.

Collard, P., \& Looney, J. (2019). Nurturing Creativity in Education. European Journal of Education, 49(3), 349-364. https://doi.org/10.1111/ejed.12090

Craft, A. (2012). The limits to creativity in education: dilemams for the educator. British Journal of Educational Studies, 51(2), 113-127. https://doi.org/10.1111/1467-8527.t01-100229

Darmawati, Amelia, P., \& Srifatimini, E. (2011). Peningkatan pembelajaran genetika dan evolusi melalui model pembelajaran Problem Based Learning (PBL) pada mahasiswa biologi FKIP UNRI. Jurnal Pilar Sains, 11(1), 29-37.

Dormalewska, D. (2014). Technology-supported classroom for collaborative learning : Blogging in the foreign language classroom. Internasional Journal of Education and Devolepment UsingInformation and Communication Technology (IJEDICT), 10(4), 21-30.

Handayani, C. F., Sunarto, W., \& Sumarti, S. S. (2017). Penerapan model pembelajaran guided discovery melalui kegiatan praktikum pada materi stoikiometri larutan, 11(1), 1840-1848.

Hera, R. (2017). Studi kasus permasalahan dalam proses pembelajaran konsep genetika di SMA Negeri 2 Seulium kabupaten ach besar. Jurnal Genta Mulia, VIII(1), 53-63.

Inganah, S., Jamil, A. F., \& Dintarini, M. (2018). Peningkatan aktifitas kolaboratif dan hasil belajar siswa melalui guided discovery learning berbantuan puzzel. Jurnal Derivat, 5(2), 42-50.

Laal, M., \& Mohammad, S. (2012). Benefits of collaborative learning Marjan. Journal Procedia Social and Behavioral Sciences, 31(11), 486-490. https://doi.org/10.1016/j.sbspro.2011.12.091

Miharja, F. J., Hindun, I., Fauzi, A. (2019). Critical thinking, metacognitive skills, and cognitive learning outcomes: A correlation study in genetic Fuad. Jurnal Pendidikan Biologi, 12(2), 135-143. https://doi.org/10.21009/biosferjpb.

Monroe, M., \& Ernst, J. (2014). The effects of environment-based education on students , critical thinking skills and disposition toward critical thinking. Journal Environmental Education Research, 10(4), 508-521. https://doi.org $/ 10.1080 / 1350462042000291038$

Musfiroh, U., Susantini, E., \& Kuswanti, N. (2012). Pengembangan modul pembelajaran berorientasi guided discovery pada materi sistem peredaran darah. Jurnal Pendidikan Biologi Unnesa, 1(2), 37-40.

Noviyanti, E., Ristanto, R. H., \& Rusdi. (2019). 
Guided discovery learning based on internet and self concept: enhancing student 's critical thinking in Biology. Indonesian Journal of Biology and Education, 2(1), 7-14.

https://doi.org/10.31002/ijobe.v2i1.1196

Nurkamila, M. (2017). Upaya meningkatkan keingintahuan matematis siswa menggunakan guided discovery learning setting kolaboratif. Jurnal THEOREMS (The Original Research of Mathematics), 1(2), 51-63.

Purwanto, C. E., Nughoro, S. E., \& Wiyanr=to. (2012). Penerapan model pembelajaran guide discovery pada materi pemantulan cahaya untuk meningkatkan berpikir kritis. Jurnal Unnes Physic Education, 1(1), 21-32.

Puzio, K., Colby, G. T., \& Colby, G. T. (2013). Journal of Research on Educational Cooperative Learning and Literacy: A meta-analytic review cooperative learning and literacy: A MetaAnalytic Review. Journal of Research on Educational Effectiveness, 6(4), 37-41. https://doi.org/10.1080/19345747.2013.77568 3

Redhana, I. W. (2019). Mengembangkan ketrampilan abad - 21 dalam pembelajaran kimia. Jurnal Inovasi Pendidikan Kimia, 13(1), 2239-2253.

Rochayati, I. H. (2016). Peningkatan kreativitas belajar ipa melalui strategi guided discovery learning. Jurnal Pendidikan Guru Sekolah Dasa, 33(5), 121-130.

Roosyanti, A. (2017). Pengembangan perangkat pembelajaran berorientasi pendekatan guided discovery untuk melatihkan ketrampilan berfikir kritis dan kreatif. Jurnal Pena Sains, 4(1), 60-73.

Sarhim, F. P., \& Harahap, F. (2015). Identifikasi miskonsepsi siswa pada materi genetika di kelas XII IPA SMA Negeri 13 Medan tahun pembelajaran 2014 / 2015. Jurnal Pelita Pendidikan, 3(4), 162-170.

Sudarisman, S. (2015). Memahami hakikat dan karakteristik pembelajaran biologi dalam upaya menjawab tantangan abad 21 serta optimalisasi implementasi kurikulum 2013. Jurnal Florea, 2(1), 29-35.

Utami, A. P. (2013). Kemampuan komunikasi, kolaborasi metakognisi dan hasil belajar mata pelajaran pelajaran teknologi mekanik siswa kelas X pada penerapan pendekatan saintifik SMKN 1 Kediri. Jurnal Pendidikan Teknik Mesin (JTPM), 5(3), 17-26.

Wasonowati, R. rosidah tri, Redjeki, T., \& Ariani, S. R. D. (2014). Penerapan model Problem Based Learning (pbl) pada pembelajaran hukum-hukum dasar kimia ditinjau dari aktivitas dan hasil belajar siswa kelas X ipa SMA Negri 2 surakarta tahun pelajaran 2013-2014. Jurnal Pendidikan Kimia (JPK), 3(3), 66-75.

Widodo, S., \& Wardani, R. K. (2020). Mengajarkan ketrampilan abad 21 4C (communication, collaboration, critical thinking and problem solving, creativity, and inovation)di sekolah dasar. Jurnal Program Studi PGMI, 7(2), 185-197. 